\title{
Preventive Behaviors among Parents towards Hand, Foot, and Mouth Diseases in Selangor using Health Belief Model
}

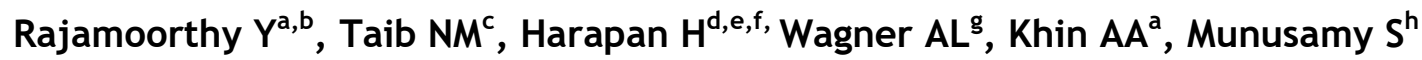 \\ ${ }^{a}$ Department of Economics, Faculty of Accountancy and Management, Universiti Tunku Abdul Rahman, Cheras, Selangor, Malaysia \\ ${ }^{b}$ Centre for Economic Studies, Universiti Tunku Abdul Rahman, Kampar, Perak, Malaysia \\ ${ }^{c}$ Department of Medical Microbiology and Parasitology, Faculty of Medicine and Health Science, Universiti Putra Malaysia, UPM Serdang, Selangor, \\ Malaysia \\ ${ }^{d}$ Department of Microbiology, School of Medicine, Universitas Syiah Kuala, Banda Aceh, Indonesia; \\ ${ }^{e}$ Medical Research Unit, School of Medicine, Universitas Syiah Kuala, Darussalam, Banda Aceh, Indonesia; \\ ${ }^{f}$ Tropical Disease Centre, School of Medicine, Universitas Syiah Kuala, Banda Aceh, Indonesia \\ ${ }^{g}$ Department of Epidemiology, University of Michigan, Ann Arbor, Michigan, United States of America \\ ${ }^{h}$ School of Management and Business, Manipal International University, 71800 Putra Nilai, Negeri Sembilan, Malaysia
}

\section{ABSTRACT}

\section{Keywords}

hand foot mouth disease, health belief model, behaviour, public health, preventive medicine, Malaysia

Corresponding Author

Dr. Yogambigai Rajamoorthy

Universiti Tunku Abdul Rahman, Sungai

Long Campus, Jalan Sungai Long, Bandar

Sungai Long, Cheras 43000, Kajang,

Selangor.

Tel. No: +603-90860288

E-mail: yogambigai@utar.edu.my

Received: 14th June 2020; Accepted: 3rd September 2021

Doi: https://doi.org/10.31436/imjm.v21i1
INTRODUCTION: Hand, foot mouth disease (HFMD) is caused by a virus and commonly affects children five years or below. However, the determinants of the associated factors with preventive behaviour among parents are still lacking. This study aims to assess the range of preventive behaviour towards HFMD among parents in Selangor, Malaysia. MATERIALS AND METHODS: A cross-sectional survey was conducted using a convenient sampling method. The associations between independent variables and preventive behaviours were assessed with multivariate regressions. RESULTS: In total, 556 parents completed the survey. The majority of the parents had good preventive behaviours towards HFMD. Age, gender, income, perceived susceptibility, and perceived benefit were associated with preventive behaviour. CONCLUSION: Although, the preventive behaviour of HFMD among parents is crucial, however, it is influenced by parents' perceptions. The strategies to enhance the parent's perception are needed to increase the preventive behaviour towards HFMD infection.

\section{INTRODUCTION}

In the last decade, outbreaks of hand foot mouth disease (HFMD) have been reported in the Western Pacific Region, including in Malaysia. ${ }^{1}$ Although HFMD can affect any age group, it is common among children less than five years. The illness is usually not serious, but it is very contagious. ${ }^{1,2}$ The transmission is predominantly via the oral-fecal route, but also through contact with viruscontaminated oral secretions, vesicular fluid, surfaces, and fomites. It can also be transmitted through direct contact with a patient's aerosolised respiratory droplets. ${ }^{3}$ HFMD is a systemic infection caused by human enteroviruses from the family of Picornaviridae. ${ }^{4}$ Most human enteroviruses cause self-limited infections except polioviruses, enterovirus A71 (EV-A71), enterovirus D68
(EV-D68), and several echoviruses (Echo) and coxsackieviruses (CV). Enterovirus especially EV-A71 has repeatedly caused large-scale outbreaks in the Asia-Pacific region since 1997.5 EV-A71 can cause serious neuropathology and cardiopulmonary complications, including aseptic meningitis, acute flaccid paralysis, brainstem encephalitis, and fatal myocarditis and pulmonary oedema. ${ }^{3}$

Patients with uncomplicated EV illness bring significant economic and medical impacts on society. Patients miss approximately 1-4 days of school or work. Direct medical costs are \$69-771 USD per case and indirect costs of $\$ 63$ -422 USD per case is mainly attributable to parental 
missed work. ${ }^{5}$ Kisling and Das ${ }^{6}$ grouping the preventive strategies into primordial prevention, primary prevention, secondary prevention, and tertiary prevention. This study is focused on the primary prevention of HFMD by determining the parents' behaviours and activities that would expose their kids to HFMD infection. Since young children are commonly affected group, ${ }^{7}$ parents behaviour plays an important role in preventing HFMD and identifying the early stage of severe HFMD symptoms. ${ }^{8}$ In Malaysia, studies have been conducted on HFMD in regards to knowledge, awareness, risk factors, and laboratory-based research ${ }^{9}$ but it is inadequate in regards to parents' preventive behaviours. Parents play an important role as health promoters in their children's lives. ${ }^{10}$ Moreover, parents' knowledge ${ }^{11}$ and perception ${ }^{12}$ are important determinants of parents' behaviours towards HFMD.

Parents' preventive behaviours are crucial to reducing the infection rate among children and emphasizing prevention may be more cost-effective than treatment. Perceptions are an important element to determine prevention behaviours. Even though the previous study was conducted to investigate the prevention behaviour of mothers on HFMD, however, this study included fathers as well. Therefore, the present study was conducted to overcome the scarcity of studies on HFMD preventive behaviours among parents in Malaysia. This study was designed to assess the parent's perception of preventive behaviour for HFMD using the Health Belief Model (HBM). This study was conducted in Selangor state in Malaysia, which is 2018, had the highest number of HFMD cases compared to other states. ${ }^{13}$

\section{MATERIALS AND METHODS}

\section{Ethical clearance}

The Scientific and Ethical Review Committee of Universiti Tunku Abdul Rahman approved the study protocol (approval U/SERC/17/2020). A brief explanation of the study was given to all participants and written informed concern was obtained from all participants. Participation was voluntary, anonymous, and no direct financial compensation was offered.

\section{Survey design and sampling method}

A cross-sectional survey was conducted in Selangor state which encircles the capital Kuala Lumpur. The state is the most populated state in Malaysia and consists of nine districts: Gombak, Klang, Kuala Langat, Kuala Selangor, Petaling, Sebak Bernam, Sepang, Ulu Langat and Ulu Selangor. To represent the population, a few kindergartens from each district were randomly selected. The sample size for this project was calculated using Raosoft Sample Size Calculator (http:// www.raosoft.com/samplesize) as used previously. ${ }^{14,15,16}$ As a minimal sample size, 385 participants were required on the following assumptions: (a) $50 \%$ of population has good perception; (b) 5\% margin of error; and (c) $95 \%$ confidence level. The participants were selected using a convenient sampling method. Using the nine administrative districts in Selangor as a sampling frame, the number of samples from each district was calculated based on its population size proportion (i.e. high numbers in some districts and low in some districts). A convenience sample of participants was recruited from each kindergarten using a quota to meet the calculated sample size for each district. Prior to starting the study, we doubled up the sample size to 770 to avoid an insufficient sample size due to incomplete data.

\section{Study instrument and data collection}

To assess the parent's preventive behaviour towards HFMD, a self-administered survey was planned from 13 January to $1^{\text {st }}$ April 2020. It required approximately 10 min to complete the survey. The survey was conducted by distributing a dual-language questionnaire (Malay and English) to the parents through the kindergarten teachers and collected after completing the answer. The selfadministered questionnaire includes socio-demographic characteristics and perceptions using the Health Belief Model. Socio-demographic characteristics included age, gender, race, education, and income.

Nine measures of preventive behaviour were included in this study and each was rated on a Likert scale from 1 (strongly disagree) to 5 (strongly agree), in which a higher score indicated a more positive preventive behaviour. 
This variable was adapted from a previous study. ${ }^{13}$ The Cronbach's alpha coefficient was 0.806. Subsequently, responses within the preventive domain using the 1 to 5 scale were summed giving a preventive behaviour score ranging from 9 to 45 in which a higher score indicated a more positive preventive behaviour.

Key elements of this Health Belief Model (HBM) focus on parental belief about health conditions, which predict preventive behaviours. This Health Belief Model included perceived susceptibility (3 items), perceived severity (4 items), perceived benefit (4 items), and perceived barriers (3 items) to prevent transmission of HFMD in their children. All questions were assessed in a Likert scale format, ranging from "strongly disagree" (score 1 point) to "strongly agree" (scores 5 points). A higher score indicated that a positive perception towards HFMD. Cronbach's alpha coefficient was 0.665 for perceived susceptibility, 0.641 for perceived severity, 0.800 for perceived benefit, and 0.806 for perceived barriers. Similar to the independent variable, the responses were summed within the construct.

This Health Belief Model represents a theoretical model that can be used to explain and predict individual changes in health behaviors. It is one of the most widely used models for understanding health behaviors.

\section{Statistical analysis}

The correlation between constructs was assessed with a Pearson's correlation coefficient. The association between the independent and explore variables were assessed using multivariate regression. Data were analysed using SPSS23 software and all analysis assessed at $\mathrm{p}<0.05$ was considered statistically significant.

\section{RESULTS}

\section{Respondents' characteristics}

We received 690 participant responses during the study period and 134 data were excluded from the final analysis due to missing information. A total of $556(80.6 \%)$ participants from all districts of Selangor were analysed.
More than half of the respondents were mothers (69.8\%) compared to fathers (30.25\%). Approximately $74 \%$ of the participants were 31 and 40 years old. A plurality of the parents had a bachelor's degree (37.9\%) followed by senior secondary education (34.9\%). The participants' race reflected that of Selangor state, with 64.7\% Malay, $21.9 \%$ Chinese, and 12.4\% Indian. Monthly income ranged most typically ranged between RM1001 to RM3000 (31.7\%) or was RM 7000 and above (27.5\%) (Table 1).

Table 1: Respondents' demographic characteristic in a survey on HFMD in Selangor, Malaysia $(\mathrm{n}=556)$

\begin{tabular}{|c|c|c|}
\hline Variable & $\mathrm{N}$ & $(\%)$ \\
\hline \multicolumn{3}{|l|}{ Gender } \\
\hline Male & 168 & 30.2 \\
\hline Female & 388 & 69.8 \\
\hline \multicolumn{3}{|l|}{ Age (years) } \\
\hline $20-30$ & 65 & 11.7 \\
\hline $31-40$ & 411 & 73.9 \\
\hline $41-50$ & 74 & 13.3 \\
\hline $51-60$ & 6 & 1.1 \\
\hline \multicolumn{3}{|l|}{ Race } \\
\hline Malay & 360 & 64.7 \\
\hline Chinese & 122 & 21.9 \\
\hline Indian & 69 & 12.4 \\
\hline Others & 5 & 0.9 \\
\hline \multicolumn{3}{|l|}{ Education } \\
\hline High school or below & 120 & 21.6 \\
\hline Certificate or diploma & 194 & 34.9 \\
\hline Bachelor's degree & 211 & 37.9 \\
\hline Postgraduate degree & 31 & 5.6 \\
\hline \multicolumn{3}{|l|}{ Household income (RM) } \\
\hline$<1000$ & 20 & 3.6 \\
\hline $1001-3000$ & 176 & 31.7 \\
\hline $3001-5000$ & 144 & 25.9 \\
\hline $5001-7000$ & 63 & 11.3 \\
\hline 7001 or above & 153 & 27.5 \\
\hline \multicolumn{3}{|l|}{ No of Kids } \\
\hline 1 & 138 & 24.8 \\
\hline 2 & 221 & 39.7 \\
\hline 3 & 113 & 20.3 \\
\hline 4 & 61 & 11.0 \\
\hline More than 5 & 23 & 4.2 \\
\hline
\end{tabular}

\section{Parents' HFMD preventive behaviour}

Most parents strongly agree with washing their hands before feeding kids (70.3\%), after using the toilet (79.5\%), and after changing diapers (75\%) (Table 2). However, only $44.2 \%$ of parents strongly agree for rubbing their hands for 20 seconds during hand washing. Only $26.8 \%$ of parents agree to use soap to clean their hands. Moreover, $57.9 \%$ of the parents strongly agree to avoid bringing kids to a public place during HFMD 
outbreak. Furthermore, parents strongly agree with preventive behaviour such as monitoring child health $(57 \%)$ and cleaning the surrounding area of kids (54\%) on daily basis.

Table 2: Distribution of answers of each question on HFMD preventive behaviour

\begin{tabular}{|c|c|c|c|c|c|}
\hline \multirow[t]{2}{*}{ Variables } & \multicolumn{5}{|c|}{$\mathrm{N}(\%)$} \\
\hline & 1 & 2 & 3 & 4 & 5 \\
\hline \multicolumn{6}{|l|}{ Preventive behaviour } \\
\hline $\begin{array}{l}\text { Cover your mouth and nose } \\
\text { with your hands when you } \\
\text { sneeze or cough }\end{array}$ & $\begin{array}{c}11 \\
(25)\end{array}$ & $\begin{array}{c}9 \\
(1.6)\end{array}$ & $\begin{array}{c}56 \\
(10.1)\end{array}$ & $\begin{array}{c}185 \\
(33.3)\end{array}$ & $\begin{array}{c}295 \\
(53.1)\end{array}$ \\
\hline $\begin{array}{l}\text { Wash your hands before } \\
\text { feeding food to your child }\end{array}$ & $\begin{array}{c}4 \\
(0.7)\end{array}$ & $\begin{array}{c}3 \\
(0.5)\end{array}$ & $\begin{array}{l}28 \\
(5)\end{array}$ & $\begin{array}{c}130 \\
(23.4)\end{array}$ & $\begin{array}{c}391 \\
(70.3)\end{array}$ \\
\hline $\begin{array}{l}\text { Wash your hands after using } \\
\text { toilet }\end{array}$ & $\begin{array}{c}5 \\
(0.9)\end{array}$ & $\begin{array}{c}2 \\
(0.4)\end{array}$ & $\begin{array}{c}19 \\
(3.4)\end{array}$ & $\begin{array}{c}88 \\
(15.8)\end{array}$ & $\begin{array}{c}442 \\
(79.5)\end{array}$ \\
\hline $\begin{array}{l}\text { Wash your hands after } \\
\text { changing diapers or cleaning } \\
\text { up a child who has used the } \\
\text { toilet }\end{array}$ & $\begin{array}{c}4 \\
(0.7)\end{array}$ & $\begin{array}{c}3 \\
(0.5)\end{array}$ & $\begin{array}{c}18 \\
(3.2)\end{array}$ & $\begin{array}{c}114 \\
(20.5)\end{array}$ & $\begin{array}{l}417 \\
(75)\end{array}$ \\
\hline $\begin{array}{l}\text { Rub your hand for at least } 20 \\
\text { seconds during hand washing }\end{array}$ & $\begin{array}{c}5 \\
(0.9)\end{array}$ & $\begin{array}{c}17 \\
(3.1)\end{array}$ & $\begin{array}{c}87 \\
(15.6)\end{array}$ & $\begin{array}{l}200 \\
(36)\end{array}$ & $\begin{array}{c}246 \\
(44.2)\end{array}$ \\
\hline $\begin{array}{l}\text { Use soap when you clean } \\
\text { your hand with water }\end{array}$ & $\begin{array}{c}3 \\
(0.5)\end{array}$ & $\begin{array}{c}5 \\
(0.9)\end{array}$ & $\begin{array}{c}66 \\
(11.9)\end{array}$ & $\begin{array}{c}149 \\
(26.8)\end{array}$ & $\begin{array}{c}333 \\
(59.9)\end{array}$ \\
\hline $\begin{array}{l}\text { Avoid bringing your child to } \\
\text { public places such as } \\
\text { department stores, } \\
\text { playgrounds, and markets } \\
\text { during the HFMD outbreak }\end{array}$ & $\begin{array}{c}18 \\
(3.2)\end{array}$ & $\begin{array}{c}26 \\
(4.7)\end{array}$ & $\begin{array}{c}70 \\
(12.6)\end{array}$ & $\begin{array}{c}120 \\
(21.6)\end{array}$ & $\begin{array}{c}322 \\
(57.9)\end{array}$ \\
\hline $\begin{array}{l}\text { Monitor your child health } \\
\text { every day }\end{array}$ & $\begin{array}{c}9 \\
(1.6)\end{array}$ & $\begin{array}{c}17 \\
(3.1)\end{array}$ & $\begin{array}{c}44 \\
(7.9)\end{array}$ & $\begin{array}{c}169 \\
(30.4)\end{array}$ & $\begin{array}{l}317 \\
(57)\end{array}$ \\
\hline $\begin{array}{l}\text { Clean areas where your child } \\
\text { eat, sit, sleep or creep every } \\
\text { day }\end{array}$ & $\begin{array}{c}10 \\
(1.8)\end{array}$ & $\begin{array}{l}15 \\
(2.7)\end{array}$ & $\begin{array}{c}72 \\
(12.9)\end{array}$ & $\begin{array}{c}159 \\
(28.6)\end{array}$ & $\begin{array}{l}300 \\
(54)\end{array}$ \\
\hline
\end{tabular}

\section{Perception of parents regarding HFMD}

On the dimension of perceived susceptibility, most parents agreed about avoiding bringing their kids to a playground (64.7\%) and not sending them to school during an outbreak (68.7\%) (Table 3).

For perceived severity, parents agreed that HFMD is to be treated by a doctor $(41.7 \%)$ and with available medication $(38.3 \%)$. On the dimension of perceived benefit, parents agreed to not send infected kids to school $(64.6 \%)$ and to practice handwashing using soap to prevent HFMD (56.8\%) and monitoring kids' health status during the outbreak (63.3\%) are the actions to reduce the threat of HFMD. A minority of parents expressed barriers with agreed to be unable to regularly practice handwashing $(15.6 \%)$
Table 3: Distribution of answers of each question within perception domain on HFMD

\begin{tabular}{|c|c|c|c|c|c|}
\hline \multirow[t]{2}{*}{ Variables } & \multicolumn{5}{|c|}{$\mathrm{N}(\%)$} \\
\hline & 1 & 2 & 3 & 4 & 5 \\
\hline \multicolumn{6}{|l|}{ Perceived susceptibility } \\
\hline $\begin{array}{l}\text { I believe children at the } \\
\text { age of less than } 5 \text { years } \\
\text { old have a higher risk of } \\
\text { getting infected with } \\
\text { HFMD than older } \\
\text { children. }\end{array}$ & $\begin{array}{c}17 \\
(3.1)\end{array}$ & $\begin{array}{c}18 \\
(3.2)\end{array}$ & $\begin{array}{c}41 \\
(7.4)\end{array}$ & $\begin{array}{c}168 \\
(30.2)\end{array}$ & $\begin{array}{c}312 \\
(56.1)\end{array}$ \\
\hline $\begin{array}{l}\text { I feel worried to bring my } \\
\text { child to the playground } \\
\text { during a HFMD } \\
\text { outbreak. }\end{array}$ & $\begin{array}{c}10 \\
(1.8)\end{array}$ & $\begin{array}{c}9 \\
(1.6)\end{array}$ & $\begin{array}{c}30 \\
(5.4)\end{array}$ & $\begin{array}{c}147 \\
(26.4)\end{array}$ & $\begin{array}{c}360 \\
(64.7)\end{array}$ \\
\hline $\begin{array}{l}\text { I am likely to stop the } \\
\text { transmissions of HFMD } \\
\text { by not sending my } \\
\text { infected child to school. } \\
\text { Perceived severity }\end{array}$ & $\begin{array}{c}9 \\
(1.6)\end{array}$ & $\begin{array}{c}14 \\
(2.5)\end{array}$ & $\begin{array}{l}39 \\
(7)\end{array}$ & $\begin{array}{c}112 \\
(20.1)\end{array}$ & $\begin{array}{c}382 \\
(68.7)\end{array}$ \\
\hline $\begin{array}{l}\text { I think that HFMD is a } \\
\text { very severe disease. } \\
\text { I think that all HFMD } \\
\text { patients will need hospital } \\
\text { admission. }\end{array}$ & $\begin{array}{c}9 \\
(1.6) \\
29 \\
(5.2)\end{array}$ & $\begin{array}{c}27 \\
(4.9) \\
104 \\
(18.7)\end{array}$ & $\begin{array}{c}105 \\
(18.9) \\
195 \\
(35.1)\end{array}$ & $\begin{array}{c}253 \\
(45.5) \\
127 \\
(22.8)\end{array}$ & $\begin{array}{c}162 \\
(29.1) \\
101 \\
(18.2)\end{array}$ \\
\hline $\begin{array}{l}\text { I think that HFMD can } \\
\text { be treated by a doctor. } \\
\text { I think there is an } \\
\text { available medication that } \\
\text { can kill the causative } \\
\text { agent of HFMD. } \\
\text { Perceived benefit }\end{array}$ & $\begin{array}{l}14 \\
(2.5) \\
22 \\
(4)\end{array}$ & $\begin{array}{c}26 \\
(4.7) \\
50 \\
(9)\end{array}$ & $\begin{array}{c}114 \\
(20.5) \\
148 \\
(26.6)\end{array}$ & $\begin{array}{c}232 \\
(41.7) \\
213 \\
(38.3)\end{array}$ & $\begin{array}{c}170 \\
(30.6) \\
123 \\
(22.1)\end{array}$ \\
\hline $\begin{array}{l}\text { I am willing to stop } \\
\text { sending my infected child } \\
\text { to school. }\end{array}$ & $\begin{array}{c}5 \\
(0.9)\end{array}$ & $\begin{array}{c}15 \\
(2.7)\end{array}$ & $\begin{array}{c}32 \\
(5.8)\end{array}$ & $\begin{array}{c}145 \\
(26.1)\end{array}$ & $\begin{array}{c}359 \\
(64.6)\end{array}$ \\
\hline $\begin{array}{l}\text { I believe practicing } \\
\text { handwashing using soap } \\
\text { can prevent HFMD } \\
\text { infection. }\end{array}$ & $\begin{array}{c}7 \\
(1.3)\end{array}$ & $\begin{array}{c}13 \\
(2.3)\end{array}$ & $\begin{array}{c}44 \\
(7.9)\end{array}$ & $\begin{array}{c}176 \\
(31.7)\end{array}$ & $\begin{array}{c}316 \\
(56.8)\end{array}$ \\
\hline $\begin{array}{l}\text { I believe it is beneficial to } \\
\text { monitor my child's health } \\
\text { status during the HFMD } \\
\text { outbreak. }\end{array}$ & $\begin{array}{c}7 \\
(1.3)\end{array}$ & $\begin{array}{c}2 \\
(0.4)\end{array}$ & $\begin{array}{c}36 \\
(6.5)\end{array}$ & $\begin{array}{c}159 \\
(28.9)\end{array}$ & $\begin{array}{c}352 \\
(63.3)\end{array}$ \\
\hline $\begin{array}{l}\text { I believe a vaccine for } \\
\text { HFMD is one of the best } \\
\text { ways to prevent the } \\
\text { infection if available. } \\
\text { Perceived barrier }\end{array}$ & $\begin{array}{c}12 \\
(2.2)\end{array}$ & $\begin{array}{c}17 \\
(3.1)\end{array}$ & $\begin{array}{c}87 \\
(15.6)\end{array}$ & $\begin{array}{c}171 \\
(30.8)\end{array}$ & $\begin{array}{c}269 \\
(48.4)\end{array}$ \\
\hline $\begin{array}{l}\text { I believe it is crucial to } \\
\text { wash my child's toys } \\
\text { regularly using the liquid } \\
\text { disinfectant. }\end{array}$ & $\begin{array}{c}5 \\
(0.9)\end{array}$ & $\begin{array}{c}14 \\
(2.5)\end{array}$ & $\begin{array}{c}61 \\
\text { (11) }\end{array}$ & $\begin{array}{c}206 \\
(37.1)\end{array}$ & $\begin{array}{c}270 \\
(48.6)\end{array}$ \\
\hline $\begin{array}{l}\text { I feel I would not be able } \\
\text { to correctly practice } \\
\text { handwashing habits } \\
\text { regularly. }\end{array}$ & $\begin{array}{c}116 \\
(20.9)\end{array}$ & $\begin{array}{c}141 \\
(25.4)\end{array}$ & $\begin{array}{l}100 \\
(18)\end{array}$ & $\begin{array}{c}112 \\
(20.1)\end{array}$ & $\begin{array}{c}87 \\
(15.6)\end{array}$ \\
\hline $\begin{array}{l}\text { I feel my family would } \\
\text { not agree if I separate my } \\
\text { HFMD infected child's } \\
\text { utensil-like cup from the } \\
\text { use of other family } \\
\text { members. }\end{array}$ & $\begin{array}{c}186 \\
(33.5)\end{array}$ & $\begin{array}{c}145 \\
(26.1)\end{array}$ & $\begin{array}{c}73 \\
(13.1)\end{array}$ & $\begin{array}{c}84 \\
(15.1)\end{array}$ & $\begin{array}{c}68 \\
(12.2)\end{array}$ \\
\hline
\end{tabular}
members. 
or helping a child use the toilet (75\%). However, only $44.2 \%$ of the parents strongly agree to rub hand for at least 20 seconds during hand washing.

Table 4: Pearson Correlation coefficient between constructs in a survey on HFMD in Selangor, Malaysia $(n=556)$.

\begin{tabular}{|c|c|c|c|c|c|}
\hline Construct & $\begin{array}{l}\text { Preventive } \\
\text { behaviour }\end{array}$ & $\begin{array}{l}\text { Perceived } \\
\text { susceptibility }\end{array}$ & $\begin{array}{l}\text { Perceived } \\
\text { severity }\end{array}$ & $\begin{array}{l}\text { Perceived } \\
\text { benefit }\end{array}$ & $\begin{array}{l}\text { Perceived } \\
\text { barriers }\end{array}$ \\
\hline $\begin{array}{l}\text { Preventive } \\
\text { behaviour }\end{array}$ & 1 & $0.490^{* *}$ & $0.237^{\text {** }}$ & $0.542^{* *}$ & 0.063 \\
\hline $\begin{array}{l}\text { Perceived } \\
\text { susceptibility }\end{array}$ & $0.490^{* *}$ & 1 & $0.278^{* *}$ & $0.628^{* *}$ & -0.001 \\
\hline $\begin{array}{l}\text { Perceived } \\
\text { severity }\end{array}$ & $0.237^{* *}$ & $0.278^{* *}$ & 1 & $0.383^{* *}$ & $0.317^{* *}$ \\
\hline $\begin{array}{l}\text { Perceived } \\
\text { benefit }\end{array}$ & $0.542^{* *}$ & $0.628^{* *}$ & $0.383^{* *}$ & 1 & $0.085^{*}$ \\
\hline $\begin{array}{l}\text { Perceived } \\
\text { barriers }\end{array}$ & 0.063 & -0.001 & $0.317^{* *}$ & $0.085^{*}$ & 1 \\
\hline
\end{tabular}

The Pearson correlation shows that preventive behaviour has a positive relationship with perceived susceptibility, perceived severity and perceived benefit, and perceived barriers. All the HBM constructs except for perceived barriers have a significant relationship with preventive behaviour (Table 4).

Table 5 presents the result of the multivariate regression. The result shows that $34.6 \%$ of the variance of preventive behaviour is explained by the explanatory variables used.

These findings indicate that age, male, income, perceived susceptibility, and perceived benefit is significant predictor for the parents' preventive behaviour. A $1 \%$ increase in parents' perceived susceptibility and perceived benefit causes $24 \%$ and $37.1 \%$ respectively increase in preventive behaviour of parents towards HFMD. Moreover, ' $1 \%$ increase in parents' income causes a $9.4 \%$ increase in their preventive behaviour. Yet, being male and increasing in age causes the preventive behaviour to reduce to $6.8 \%$ and $6.3 \%$ respectively.

\section{DISCUSSION}

This study used the HBM to examine preventive behaviours for HFMD among parents in Malaysia. Several important findings indicated that perceived susceptibility influence parental preventative behaviours. First, parents with kids younger than 5-years perceive that playgrounds and schools are important sources of

\begin{tabular}{lcccc} 
Table 5: Regression analysis of preventive behaviour \\
\hline Variables & $\begin{array}{c}\text { Standardised } \\
\text { coefficient }\end{array}$ & Std. error & \multicolumn{2}{c}{$95 \%$ CI } \\
\cline { 3 - 5 } & & & $\begin{array}{c}\text { Lower } \\
\text { bounded }\end{array}$ & $\begin{array}{c}\text { Upper } \\
\text { bounded }\end{array}$ \\
\hline Age & $-0.063^{*}$ & 0.034 & -0.128 & 0.006 \\
Malay & 0.003 & 0.379 & -0.713 & 0.776 \\
Degree & -0.057 & 0.392 & -1.341 & 0.201 \\
Male & $-0.068^{*}$ & 0.384 & -1.493 & 0.015 \\
lncome & $0.094^{* *}$ & 0.247 & 0.114 & 1.085 \\
Perceived & $0.240^{* * *}$ & 0.106 & 0.358 & 0.776 \\
susceptibility & 0.021 & 0.067 & -0.097 & 0.168 \\
Perceived & & & & \\
severity & $0.371^{* * *}$ & 0.091 & 0.539 & 0.896 \\
Perceived & & & -0.064 & 0.217 \\
benefit & 0.040 & 0.071 & & \\
$\begin{array}{l}\text { Perceived } \\
\text { barriers }\end{array}$ & & & & \\
N & 556 & & & \\
R2 & 0.346 & & & \\
$\begin{array}{l}\text { Durbin- } \\
\text { Watson }\end{array}$ & 1.959 & & & \\
F-statistic & $32.039 * * *$ & & & \\
\hline
\end{tabular}

Note: $*$ Significance at $0.10,{ }^{* *}$ Significance at $0.05,{ }^{* * *}$ Significance at 0.01

susceptibility of HFMD transmission to their children. However, prevention by washing toys is not favourable by the parents. Similar findings of washing the toys were perceived as a barrier and could be troublesome to the parents in the previous local study. ${ }^{17}$ De et al. ${ }^{7}$ mentions that the main prevention step taken in China during the HFMD outbreak was sterilization of toys, and frequent hand washing for high-risk groups. Moreover, a study conducted in Vietnam revealed that nurses and other health care providers should educate mothers to clean children's toys to prevent HFMD infections. ${ }^{18}$

Our study reveals that preventive behaviour is seen among parents who perceived benefit, followed by perceived susceptibility. Socioeconomic status was significantly related to preventive bahaviour such as parents' monthly income, age, and being male. In this study, we found a positive relationship between parents' preventive behaviour and income. In contrast, a previous local study reported that socioeconomic factors are not associated with parents' preventive bahaviour. ${ }^{17}$ However, monthly income was associated with good preventive behaviours for HFMD in Thailand ${ }^{19}$ and Taiwan ${ }^{20}$. Yet, a study conducted in China reported that parents' monthly income has an indirect effect on their preventive behaviour towards HFMD. ${ }^{21}$ 
We found that as the parents' age increases their preventive behaviour towards HFMD decrease. A study conducted on perception and age indicates that the elderly age group is less likely to engage in preventive health behaviour even though these behaviours benefit them. ${ }^{22}$ Another study reported that age plays an important role in health-related bahaviour patterns. ${ }^{23}$ This indicates that as the parents' age increases, their commitment to their job and responsibility also increases causes some parents to take less preventive bahaviour towards HFMD.

Our result revealed that male has less preventive behaviour towards HFMD. However, a study conducted in Thailand on preventive behaviour towards HFMD among caregivers of children under five years shows that gender has a significant influence on theirs study. ${ }^{24}$ Moreover, another study conducted in Thailand on child guardian revealed the same outcome. ${ }^{25}$ Furthermore, a study conducted in rural Austrian country shows that female has more health behaviour compared to men. ${ }^{26}$ Moreover, a study conducted in Singapore reported that preventive behaviour has difference among gender regardless ethnicity or social background. ${ }^{27}$ Yet, another study suggested that cultural factors in different ethnicities may play a role in health behaviour. ${ }^{28}$ However, our findings show that ethnicity is not significant with the preventive behaviour of the parents.

We found that perceived susceptibility has a positive relationship with preventive behaviour. Similar findings were reported in the local study. ${ }^{17}$ Yet, Nuankerd and Mekrungruangwong 25 reported that perceived susceptibility is not significant with preventive behaviour. Perceived susceptibility refers to the subjective perception of the risk of contracting a health condition. ${ }^{29}$ This indicates that parents perceived their kids as a vulnerable group of the HFMD. This causes the parents to take preventive behaviour to avoid their kids being infected by HFMD. Wang et al. ${ }^{21}$ found that perceived barriers have a direct effect on parents' preventive behaviour. However, in our study perceived barriers do not influence parents' preventive behaviour.
Perceived benefit refers to the effectiveness of various actions available in reducing the disease threat. ${ }^{29}$ Parents are motivated to adopt new behaviour to avoid HFMD infection. Our study shows that the perceived benefit is the important and main factor that influences parents' preventive behaviour. Both studies conducted in Thailand revealed the same outcome. ${ }^{25,30}$ This indicates that parents are well known of the infection and they avoid it by doing some prevention by changing their preventive behaviours.

\section{Strengths and limitations}

A strength of this study was its sampling of diverse families across a populous state of Malaysia. However, we note several limitations. By using convenience sampling of families within kindergartens, we possibly are introducing sampling bias into the study. Other variables may affect preventive behaviours and which we did not consider, like social norms.

\section{CONCLUSION}

Parents' preventive behaviours toward HFMD are significantly influenced by age, gender, income, perceived susceptibility, and perceived benefit. The interventions should be developed to improve preventive behaviour, especially for elderly, male, and low-income parents. The perceived susceptibility and perceived benefits are the primary belief in attitudes towards preventive behaviour. Government should take necessary steps to educate the public regarding the susceptibility of having HFMD among their children and the benefits of practicing preventive measures of HFMD by different platforms through social media, posters at public places, social networking, or video-sharing including YouTube and Facebook. The benefits of preventing HFMD should also be regularly informed to improve parental behaviour from nursery or kindergarten or caretakers, or their respective family physicians to reduce HFMD transmission among children and to prevent outbreaks.

\section{CONFLICTS OF INTEREST}

There are no conflicts of interest 


\section{ACKNOWLEDGEMENT}

The authors would like to thank the questionnaire moderator committee from the Faculty of Health Sciences, Universiti Putra Malaysia: Dr. Rosliza Abdul Manaf, Department of Community Health, and Dr. Siti Zulaikha Binti Zakariah, Department of Medical Microbiology and Parasitology.

\section{FINDINGS}

This study was funded by Universiti Tunku Abdul Rahman Research Fund (UTARRF), grant number IPSR/RMC/UTARRF/2019-C1/Y03.

\section{REFERENCE}

1. World Health Organization. Hand, Foot and Mouth Disease Situation Update 2018. [online]. Available at: who.int/iris/bitstream/

handle/10665/207490/9789290615255_eng.pdf? sequence $=1 \&$ is Allowed $=y$ 2018. Accessed December 3, 2020, December 3.

2. Wang X, Wu X, Jia L, Li X, Li J, Li S, Qian H, Wang Q. Estimating the number of hand, foot and mouth disease amongst children aged under-five in Beijing during 2012, based on a telephone survey of healthcare seeking behavior. BMC infectious diseases. 2014 Dec;14(1):1-6.

3. Peansukwech U, Banchonhuttakit P. Disease by the Application of Health Belief Model and Social Support of Caregivers and Child's Parents in Child Care Center at Muang District, Khon Kaen Province. Srinagarind Medical Journal. 2014;29(2):158-63.

4. Gonzalez G, Carr MJ, Kobayashi M, Hanaoka N, Fujimoto T. Enterovirus-associated hand-foot and mouth disease and neurological complications in Japan and the rest of the world. International journal of molecular sciences. 2019 Jan;20(20):5201.

5. Chiu ML, Luo ST, Chen YY, Chung WY, Duong V, Dussart P, Chan YF, Perera D, Ooi MH, Thao NT, Truong HK. Establishment of Asia-Pacific network for enterovirus surveillance. Vaccine. 2020 Jan 3;38 (1):1-9.
6. Kisling LA, Das JM. Prevention strategies. StatPearls [Internet]. 2020 Jun 7.

7. De W, Changwen K, Wei L, Monagin C, Jin Y, Cong M, Hanri Z, Jun S. A large outbreak of hand, foot, and mouth disease caused by EV71 and CAV16 in Guangdong, China, 2009. Archives of virology. 2011 Jun;156(6):945-53.

8. LIU XF, YANG XT, LIU HX. Investigation of Community Residents Prevention Knowledge and Attitude on Hand-foot-mouth Disease. Chinese Primary Health Care. 2011:06.

9. Yusop YB, Ahmad NA, Nawi ZB. Exposure Towards Hand, Foot and Mouth Disease (HFMD) Awareness and Sources of Information among Caretakers. EPRA International Journal of Research and Development. 2019;4(11):73-9.

10. Case A, Paxson C. Parental behavior and child health. Health affairs. 2002 Mar;21(2):164-78.

11. Hedin K, Petersson C, Cars H, Beckman A, Håkansson A. Infection prevention at day-care centres: feasibility and possible effects of intervention. Scandinavian journal of primary health care. 2006 Jan 1;24(1):44-9.

12. Zerdo Z, Van Geertruyden JP, Massebo F, Biresaw G, Shewangizawu M, Tunje A, Chisha Y, Yohanes T, Bastiaens H, Anthierens S. Parents' perception on cause of malaria and their malaria prevention experience among school-aged children in Kutcha district, Southern Ethiopia; qualitative study. PloS one. 2020 Oct 13;15(10):e0239728.

13. Ministry of Health Malaysia: Health Indicators. [online].2018. [Available at: www.moh.gov.my/ moh/resources/Penerbitan/Penerbitan\%20Utama/ HEALTH $\% 20$ INDICATOR/Petunjuk $\%$ 20Kesihatan\%202019\%20(Web\%20Version)/ mobile/index.html. Accessed December 3, 2020.

14. Wainstein BK, Sterling-Levis K, Baker SA, Taitz J, Brydon M. Use of the Internet by parents of paediatric patients. Journal of paediatrics and child health. 2006 Sep;42(9):528-32.

15. Omair A. Sample size estimation and sampling techniques for selecting a representative sample. Journal of health specialties. 2014 Oct 1;2(4):142.

16. Harapan H, Aletta A, Anwar S, Setiawan AM, Maulana R, Wahyuniati N, Ramadana MR, Haryanto 
S, Rodríguez-Morales AJ, Jamil KF. Healthcare workers' knowledge towards Zika virus infection in Indonesia: a survey in Aceh. Asian Pacific journal of tropical medicine. 2017 Feb 1;10(2):189-94.

17. Suliman Q, Said SM, Zulkefli NA. Predictors of preventive practices towards HFMD among mothers of preschool children in Klang district. Mal J Med Health Sci. 2017;13(3):21-32.

18. Thi Nga N, Pongjaturawit $\mathrm{Y}$, Chaimongkol N. Factors Associated with Maternal Behavior in Prevention of the Hand, Foot and Mouth Disease in Young Children, Vietnam. Thai Pharmaceutical and Health Science Journal. 2016; 11(1):33-9.

19. Charoenchokpanit R, Pumpaibool T. Knowledge attitude and preventive behaviors towards hand foot and mouth disease among caregivers of children under five years old in Bangkok, Thailand. Journal of Health Research. 2013;27(5):281-6.

20. Lou ML, Lin DJ. Exploration of the Healthy Behaviors Against Enterovirus and Its Related Factors in the Caregivers of Preschool-age Children. J Hung Kuang. 2006 Nov 1;49:145-62.

21. Wang R, Kang XP, Zhang LP. Application of health belief model (HBM) in relationship of sociopsychological factors and hand-foot-mouth disease (HFMD) prevention behaviours. Chinese Journal of Health Education. 2012:11.

22. Levy BR, Myers LM. Preventive health behaviors influenced by self-perceptions of aging. Preventive medicine. 2004 Sep 1;39(3):625-9.

23. Tseng TS, Lin HY. Gender and age disparity in health-related behaviors and behavioral patterns based on a National Survey of Taiwan. International journal of behavioral medicine. 2008 Mar 1;15(1):1420.

24. Charoenchokpanit R, Pumpaibool T. Knowledge attitude and preventive behaviors towards hand foot and mouth disease among caregivers of children under five years old in Bangkok, Thailand. Journal of Health Research. 2013;27(5):281-6.

25. NUANKERD K, Mekrungruangwong S. Factors affecting the prevention behavior of Hand Foot Mouth disease among guardians in child development centers, Wangthong district, Phitsanulok province (Doctoral dissertation,
Naresuan University).

26. Stronegger WJ, Freidl W, Rasky E. Health behaviour and risk behaviour: socioeconomic differences in an Austrian rural county. Social science \& medicine. 1997 Feb 1;44(3):423-6.

27. Quah SR. Gender roles, family roles and health behaviour: pursuing the hidden link. Southeast Asian Journal of Social Science. 1990 Jan 1:51-69.

28. Lim WY, Ma S, Heng D, Bhalla V, Chew SK. Gender, ethnicity, health behaviour \& self-rated health in Singapore. BMC Public Health. 2007 Dec;7 (1):1-7.

29. Janz NK, Becker MH. The health belief model: A decade later. Health education quarterly. 1984 Mar;11(1):1-47.

30. Punthmatharith B, Kongsang L, Kongpet J, Khamchan P, Prateepchaikul L, Pulpraphai P. Predictive Factors of Preventive and Control Communicable Diseases Behaviors Among Guardians at Home. Songklanagarind Journal of Nursing. 2019 Jun 30;39(2):23-36. 